\title{
抗生剂軟膏混合による配合変化
}

\author{
川本庸太, ${ }^{a}$ 田山剛崇, ${ }^{b}$ 佐和章弘, ${ }^{b}$ 門出孝美, ${ }^{a}$ 佐島 進, ${ }^{a}$ \\ 吉岡真理, ${ }^{a}$ 三宅勝志, ${ }^{b}$ 森田修之, ${ }^{b}$ 木平健治 $*, c$
}

\section{Effect of the Admixture of Tetracycline and Nadifloxacin Ointments on Their Stability and Their Antibacterial Activity}

\author{
Tsunetaka KAWAMOTO, ${ }^{a}$ Yoshitaka TAYAMA, ${ }^{b}$ Akihiro SAWA, ${ }^{b}$ \\ Takami Monde, ${ }^{a}$ Susumu SASHIMA,${ }^{a}$ Mari YoshioKA, ${ }^{a}$ \\ Katushi MiYaKe, ${ }^{b}$ Shushi Morita, ${ }^{b}$ and Kenji KinIRA ${ }^{*, c}$ \\ ${ }^{a}$ Owl Pharmacy, My Life Co., Ltd., 1-3-12 Nakadori, Kure City 737-0046, Japan, \\ ${ }^{b}$ Laboratory of Drug Informatics, Faculty of Pharmaceutical Science, Hiroshima \\ International University, 5-1-1 Hirokoshingai, Kure City 737-0112, Japan, \\ 'Department of Pharmaceutical Services, Hiroshima University Hospital, \\ 1-2-3 Kasumi, Minami-ku, Hiroshima 734-8553, Japan
}

(Received January 25, 2008; Accepted May 7, 2008)

\begin{abstract}
Impetigo contagiosa staphylogenes is commonly treated by administering a combination of nadifloxacin and tetracycline ointments. However, it is not clear whether nadifloxacin and tetracycline are stable after mixing. The purpose of this study was to evaluate the stability of these agents in combination. We also evaluated changes in antibacterial activity after mixing. Mixing the two ointments caused tetracycline to change from yellow to brown in the admixture. Furthermore, the tetracycline content in the ointment decreased in a time-dependent manner, to about $40 \%$ at $288 \mathrm{~h}$ after mixing. In addition, the nadifloxacin content in the ointment did not change $288 \mathrm{~h}$ after mixing. In an alkaline environment ( $\mathrm{pH} 9.0$ and 11.0), the tetracycline content decreased and the color of tetracycline changed to brown. These results suggest that sodium hydroxide, which is an additive in nadifloxacin ointment, influences the content of tetracycline. We evaluated the chemical sensitivity of Staphylococcus aureus using disk tests. Nadifloxacin and tetracycline ointment showed the largest radius of inhibition circle, followed by the admixture $0 \mathrm{~h}$ after mixing and the admixture 72 $\mathrm{h}$ after mixing. These results suggest that the antibacterial activity is inhibited by the admixture. We propose that pharmacists should avoid mixing nadifloxacin with tetracycline ointment in the treatment of impetigo contagiosa staphylogenes and should take care to avoid interactions caused by additives in the ointments.
\end{abstract}

Key words — - tetracycline; nadifloxacin; ointment; antibacterial activity; interaction

\section{緒言}

皮膚科領域の薬物治療において，効果の相乗・相 加作用・副作用の軽減に加え，コンプライアンスの 向上を目的として，軟膏剂の混合調剂が多く行われ ている. ${ }^{1,2}$

また，従来，伝染性膿痂疹の薬物治療において， テトラサイクリン系抗生剤軟膏が汎用されていた が，近年，伝染性膿痂疹の MRSA に対して，二

aオール薬局, マイライフ侏, ${ }^{b}$ 広島国際大学薬学部医 療情報学講座, c広島大学病院薬剂部

*e-mail: kihirak@hiroshima-u.ac.jp
ユーキノロン系抗生剤であるナジフロキサシン軟膏 の有効性が報告され, ${ }^{3)}$ それらの併用療法が試みら れている.

これまで，副腎皮質ホルモンを中心に，軟膏剂混 合時における主薬の安定性に関して報告がなされて (る。年-8)しかし，伝染性膿痂疹の治療に使用され る抗生剂軟膏の混合時における主薬の安定性及びそ の抗菌活性については，十分な検討がなされていな い. 既に，テトラサイクリン系抗生剤であるミノマ イシンは, pH 依存的に，その色彩及び主薬量が変 化することが報告されている. ${ }^{9)}$ また，テトラサイ クリン系抗生剂は炭酸水素ナトリウムとの混合によ 
り褐色に変化し，抗菌効果が減少することも知られ ている. 10)われわれは，ニューキノロン系抗生剤で あるナジフロキサシン軟膏（アクアチム軟膏）と テトラサイクリン系抗生剂であるテトラサイクリン 軟亳（アクロマイシン®軟膏）を混合調剤した際に 色彩変化が生じることを経験し，混合により物理 的・化学的変化を生じている可能性が考えられた. 本研究では，ナジフロキサシン軟膏とテトラサイク リン軟膏の混合時における両主薬の安定性及び抗菌 活性に及ぼす影響に関して検討を行ったので報告す る.

\section{試薬と実験方法}

1. 試薬 テトラサイクリン含有軟膏としてア クロマイシン®軟膏 $[$ 科薬侏 $]$ ，ナジフロキサシン含 有軟膏としてアクアチム ${ }^{\circledR}$ 軟膏 $1 \%$ [大塚製薬侏］ を使用した。 また，標品として，テトラサイクリン 原末 [ナカライテスク秼］，ナジフロキサシン原末 （LKT Laboratories, Inc）を用いた。さらに，標準 菌株として，Staphyloccus. aureus IFO12732を使 用した。培地は，トリプケース寒天培地（Biomerieux, Inc）及び CASO 寒天培地［メルク陎］を 使用した。

2. 軟膏中主薬含量の定量方法 各軟膏に, 精 製水を加え, $20 \mathrm{mg} / \mathrm{ml}$ の溶液を作成し, $60^{\circ} \mathrm{C}$ の温 浴にて溶解した。その後，上層部分（油相）を取り 除き，下層部分 (水相) の溶液を $0.45 \mu \mathrm{m}$ フィルター でろ過した。 ろ液を精製水で 10 倍希釈後, 高速液 体クロマトグラフ（HPLC）（LC-10ADvp，島津製
作所）にて各種抗生剤の濃度を測定した。なお，ナ ジフロキサシンは，酸性条件で不安定なため，0.1 $\mathrm{N}$ 水酸化ナトリウムで $\mathrm{pH} 9.0$ に調整した溶液に, 軟膏を溶解した。テトラサイクリンの定量は，カラ ム : Cosmosil 5C $\mathrm{C}_{18}-\mathrm{MS}-\mathrm{II} \quad(4.6 \mathrm{~mm} \times 150 \mathrm{~mm})$ を 用い, カラム温度 : $35^{\circ} \mathrm{C}$, 移動相 : $20 \mathrm{mM}$ リン酸 緩衝液 : メタノール $=80: 20(\mathrm{v} / \mathrm{v})$, 流速 $: 1.0 \mathrm{ml} /$ min，検出波長：254 nm の条件で行った（Fig. 1). また，ナジフロキサシンの定量は，カラム：Inertsil ODS-3 (4.6 mm × $250 \mathrm{~mm})$ を用い，カラム温 度： $35^{\circ} \mathrm{C}$, 移動相 : $20 \mathrm{~mm}$ リン酸緩衝液 : メ夕 ノール $=45: 55(\mathrm{v} / \mathrm{v})$, 流速 $: 0.5 \mathrm{ml} / \mathrm{min}$, 検出波 長：270 nm の条件で行った（Fig. 1)。なお，本方 法にて，テトラサイクリン軟膏及びナジフロキサシ ン軟膏中に含有される主薬含量を測定した結果, $28.8 \pm 1.5(n=5)$ と $9.9 \pm 0.6 \mathrm{mg} / \mathrm{g}(\mathrm{n}=5)$ であり, 医薬品のインタビューフォームに記載されている主 薬含量は，テトラサイクリン $(30 \mathrm{mg} / \mathrm{g})$ 及びナジ フロキサシン $(10 \mathrm{mg} / \mathrm{g})$ であった. ${ }^{11,12)}$

3. 主薬含量の経時変化に及ぼす軟膏混合の検討 各種軟膏 $5 \mathrm{~g}$ を正確に秤量したものを，等量混合 し， $4^{\circ} \mathrm{C}$ ，暗所で栓を閉じた状態の軟膏盇に保存し た。なお，軟膏の混合が終了し，軟膏㽦に充填する 直前を混合 0 時として，0，24，48，72，144，288 時間 後に，混合物を採取し，それぞれの主薬含量の定量 を行った。 なお，コントロールとして，テトラサイ クリン軟膏と白色ワセリン，及びナジフロキサシン 軟膏と白色ワセリンを等量混合したものを使用した.

4. 主薬の安定性に及ぼす $\mathrm{pH}$ の影響テトラ

\section{(A) Tetracycline}

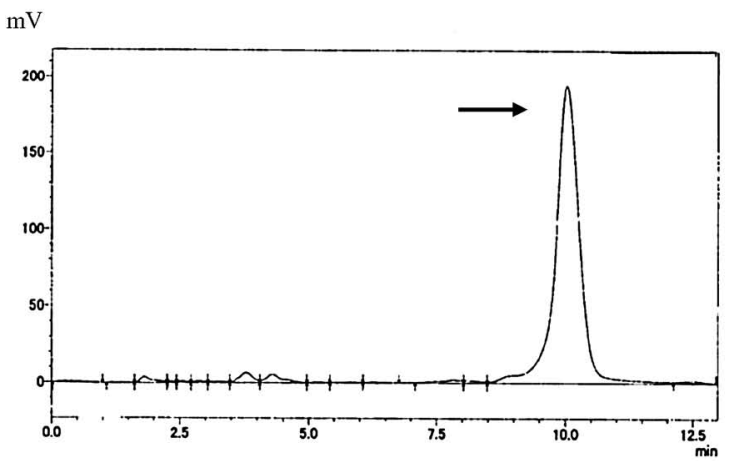

(B) Nadifloxacin

$\mathrm{mV}$

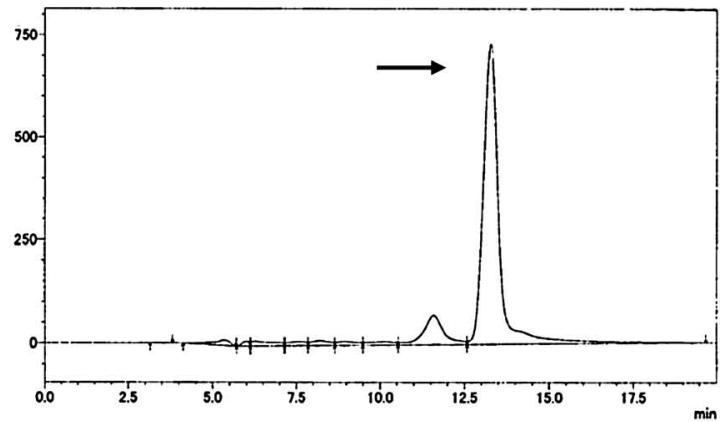

Fig. 1. Charts of Tetracycline and Nadifloxacin on HPLC 
サイクリンを精製水に溶解し， $0.2 \mathrm{mg} / \mathrm{ml}$ の溶液を 作成した. その後, $0.1 \mathrm{~N}$ 水酸化ナトリウム及び 0.1 $\mathrm{N}$ 塩酸を用いて, $\mathrm{pH}$ を 3.0, 5.0, 7.0, 9.0, 11.0 に調 整した。その後， $4^{\circ} \mathrm{C}$ ，暗所で栓を閉じた状態で保 存した。なお， $\mathrm{pH}$ を調整した時点を 0 時として， $0,1,24,48,72,144,288$ 時間後に各溶液の濃度を測 定した。また，ナジフロキサシンは，少量の dimethyl sulfoxide で溶解後，精製水にて， $0.2 \mathrm{mg}$ / $\mathrm{ml}$ の溶液を作成した。以下，テトラサイクリンと 同様な方法で検討を行った。

\section{5. 抗菌活性に及ぼす軟膏混合の影響 $S$} aureus をトリプケース寒天培地に接種し, 培養 $\left(37^{\circ} \mathrm{C}, 24 \mathrm{~h}\right)$ を行つた．ついで，培地上のコロニー を McFarland が 0.5 となるように滅菌精製水で調 整し, 接種菌液とした。

テトラサイクリン軟膏，ナジフロキサシン軟膏, 及びそれらの等量混合物，各 $20 \mathrm{mg}$ に精製水を加 え $20 \mathrm{mg} / \mathrm{ml}$ の溶液を作成し, $60^{\circ} \mathrm{C}$ の温浴にて溶解 した。 その後, 脂溶部分である上層部分を取り除 き，下層部分の溶液を $0.45 \mu \mathrm{m}$ フィルターでろ過し た。 ろ液に滅菌精製水を加え，軟膏抽出液 $(20 \mathrm{mg} /$ ml）とした.

薬剤感受性試験にはディスク拡散法を用いた。す なわち，前述の方法で調整した接種菌液を滅菌棒に て CASO 寒天培地上に異なった方向から 3 回均等 に塗布したのち，各軟膏抽出液を浸したディスクを 置いた。培養 $\left(37^{\circ} \mathrm{C}, 24 \mathrm{~h}\right)$ 後, 阻止円半径を 2 方 向から測定した。なお，等量混合軟膏は，混合直後 及び 72 時間後のものを使用した.
6. 統計処理 得られた実験値は平均土標準偏 差で表示し，有意差の検定はANOVA を用いて行 い，分散に差を認めた場合は，post hoc test を用い た。なお，危険率両側 $5 \%$ 以下 $(p<0.05)$ を有意 水準とした.

結果

1. 混合による外観の経時変化 テトラサイク リン軟膏とナジフロキサシン軟膏を等量混合後の色 彩変化を Fig. 2 に示した。混合直後では，変化が 観察されなかつたが，混合後 24 時間より褐色を呈 し，72 時間後に，黒褐色に変化した。一方，テト ラサイクリン軟膏と白色ワセリンの等量混合物及び ナジフロキサシン軟膏と白色ワセリンの等量混合物 では，288 時間後においても外観変化は観察されな かった (data not shown).

\section{2. 混合による主薬含量及び見掛けの pH の経時} 的変化 テトラサイクリン軟膏とナジフロキサシ ン軟膏を等量混合した際における両主薬の含量変化 を検討した（Fig. 3)。テトラサイクリン含量は, 混合後 24 時間で $85 \%$ の低下が観察され，288 時間 後では $40 \%$ に低下した。一方，ナジフロキサシン は，混合 288 時間においても主薬含量の変化を認め なかった。なお，各軟膏抽出液における見掛けの $\mathrm{pH}$ は，テトラサイクリン軟膏（pH 2.3），ナジフ ロキサシン軟膏（pH 12.4）であった。一方，等量 混合物の見掛けの $\mathrm{pH}$ は， 7.8 付近を示し，混合 288 時間まで一定值を示した（Fig. 4).

3. テトラサイクリン及びナジフロキサシン濃度
(A)
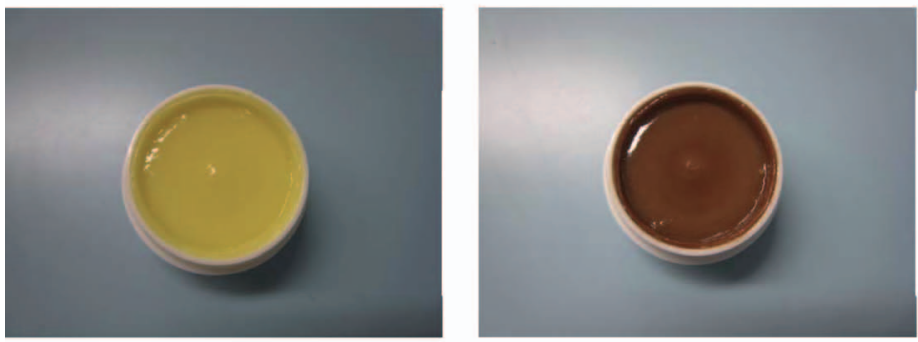

$24 \mathrm{~h}$ after mixing
(C)

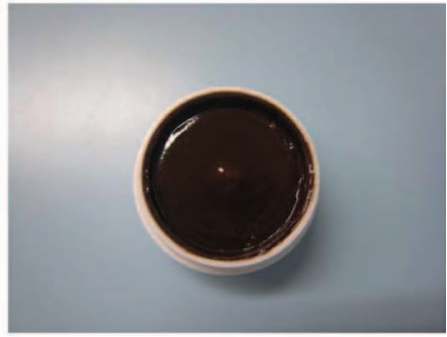

$72 \mathrm{~h}$ after mixing

Fig. 2. Changes of Color after Mixing Tetracycline and Nadifloxacin 
(A) Tetracycline

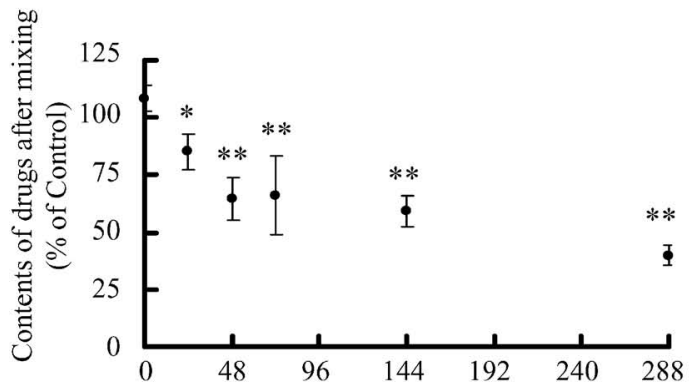

(B) Nadifloxacin

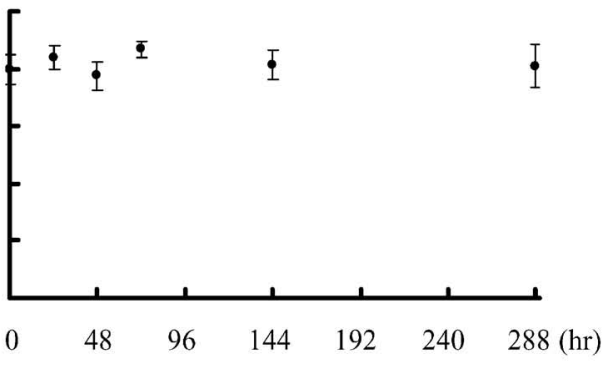

Fig. 3. (A) Changes of Tetracycline Content in the Ointment after Mixing with Nadifroxacine, (B) Changes of Nadifloxacine Content in the Ointment after Mixing with Tetracycline

Each point represents the mean \pm S.D. of 3 experiments. ${ }^{*} p<0.05,{ }^{* *} p<0.01$ vs $0 \mathrm{~h}$.

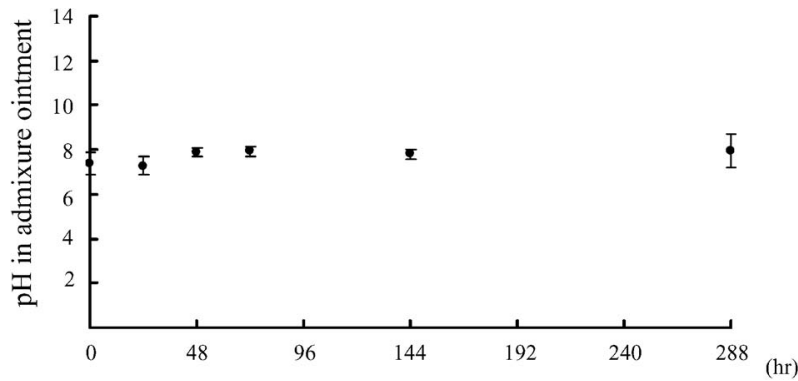

Fig. 4. Changes of $\mathrm{pH}$ in the Admixture Ointment (Tetracycline and Nadifroxacine Ointment)

Each point represents the mean \pm S.D. of 3 experiments.

\section{に及ぼす pH の影響＼cjkstart各 $\mathrm{pH}$ 溶液中におけるテト} ラサイクリン原末の安定性を Fig. 5(A) に示した. $\mathrm{pH} 3.0, \mathrm{pH}$ 5.0, 及び pH 7.0 に調整したテトラサ イクリン溶液においては，288 時間後まで，濃度の 低下は観察されなかった。一方，アルカリ条件下 （pH 9.0, pH 11.0）では，24 時間後より，濃度低下 が観察され，72 時間では 56\%（pH 11.0） 及び 80 \%（pH 9.0）を示した。 また，アルカリ条件下で は，溶解直後より黄色から黒褐色への色彩変化が観 察された。

ナジフロキサシン濃度は，酸性条件に調整した 1 時間後， $25 \%(\mathrm{pH} \mathrm{3.0)} \mathrm{及び} 47 \%(\mathrm{pH} 5.0)$ を示し， 急激な低下が観察された。その後，72 時間で 16\% （pH 3.0）及び 19\%（pH 5.0）まで低下した。一方， アルカリ条件下，濃度低下は観察されなかった (Fig. 5(B)).

4. 抗菌活性に及ぼす軟膏混合の影響 Table 1 に，テトラサイクリン軟膏，ナジフロキサシン軟 膏及びそれらを等量混合した軟膏の阻止円の直径を
示す。阻止円は，ナジフロキサシン，テトラサイク リン>混合直後の軟膏>混合 72 時間後の軟膏の順 であった。

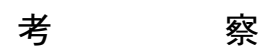

本研究では，ナジフロキサシン軟膏とテトラサイ クリン軟膏の混合による主薬の安定性及び抗菌活性 の変化について検討を行つた.

ナジフロキサシン軟膏とテトラサイクリン軟膏の 混合により，テトラサイクリン量は，24 時間で 85 \%に低下し，さらに，288 時間で 40\%を示した。一 方，ナジフロキサシンは混合 288 時間後においても その含量は変化しなかった（Fig. 3)。これらの結 果より, 混合によりナジフロキサン含量は変化しな いが，テトラサイクリン含量は減少することが示さ れた。

本研究にて検討を行ったナジフロキサシン軟膏 （アクアチム軟膏 ${ }^{\circledR} 1 \%$ ）には，主薬のナジフロキサ シンに加え, 白色ワセリン, オレイルアルコール, ステアリン酸，水酸化ナトリウムが含有されてお り，一方，テトラサイクリン軟膏（アクロマイシン 軟膏 $\left.{ }^{\circledR}\right)$ には，主薬であるテトラサイクリン塩酸塩 に加え，精製ラノリン，白色ワセリン，パラオキシ 安息香酸プロピル，パラオキシ安息香酸メチルが含 有されている（Table 2).11,12）したがって，ナジフ ロキサシン軟膏中の水酸化ナトリウムとテトラサイ クリン塩酸塩がこの配合変化に深く関与している可 能性がある.

次に，これら配合変化の要因を詳細に検討する目 的で，各 $\mathrm{pH}$ におけるテトラサイクリン濃度の変化 
(A) Tetracycline

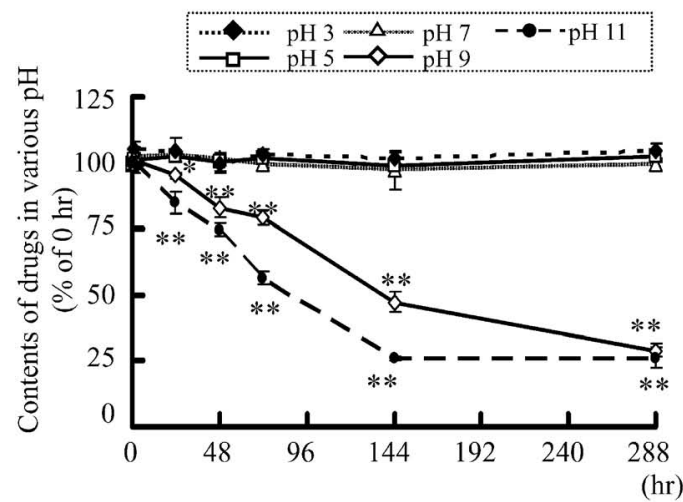

(B) Nadifloxacin

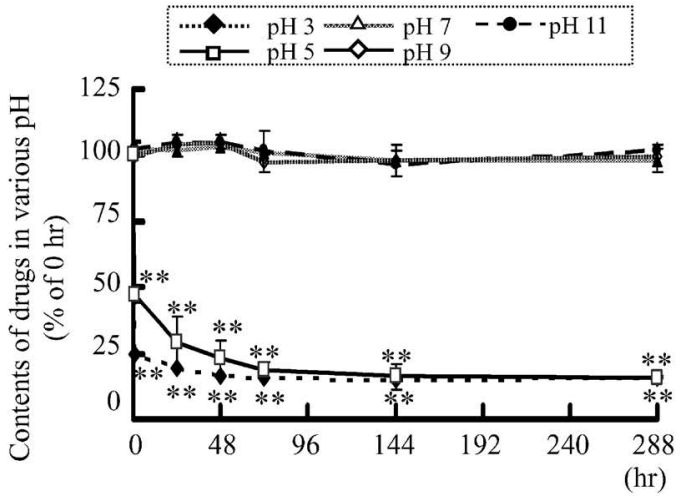

Fig. 5. (A) Changes of Tetracycline Content in Various $\mathrm{pH}$, (B) Changes of Nadifloxacine Content in Various $\mathrm{pH}$. Each point represents the mean \pm S.D. of 3 experiments. ${ }^{*} p<0.05,{ }^{* *} p<0.01$ vs $0 \mathrm{~h}$.

Table 1. Antibacterial Activity of Admixing Nadifloxacin and Tetracycline on towards $S$. aureus

\begin{tabular}{ll}
\hline \hline & \multicolumn{1}{c}{$20 \mathrm{mg} / \mathrm{ml}$} \\
\hline Tetracycline & $17.3 \pm 1.4^{* *}$ \\
Nadifloxacin & $18.0 \pm 0.9^{* *}$ \\
Admixture after $0 \mathrm{~h}$ & $15.5 \pm 0.8^{* *}$ \\
Admixture after $72 \mathrm{~h}$ & $13.5 \pm 1.0$ \\
\hline
\end{tabular}

Each value represents the mean \pm S.D. of 6 experiments. $n=6,{ }^{*} p<$ $0.05,{ }^{* *} p<0.01$ vs admixture after $72 \mathrm{~h}$.

Table 2. Additives of Tetracycline Ointment and Nadifloxacine Ointment

\begin{tabular}{|c|c|c|}
\hline & Main component & Additives \\
\hline $\begin{array}{l}\text { Nadifloxacin } \\
\text { ointment }\end{array}$ & Nadifloxacin & $\begin{array}{l}\text { White petrolatum, oleyl alco- } \\
\text { hol, stearic acid, and sodium } \\
\text { hydroxide }\end{array}$ \\
\hline $\begin{array}{l}\text { Tetracycline } \\
\text { ointment }\end{array}$ & $\begin{array}{l}\text { Tetracycline } \\
\text { hydrochloride }\end{array}$ & $\begin{array}{l}\text { Purified lanolin, white petro- } \\
\text { latum, propyl parahydrox- } \\
\text { ybenzoate, and methyl para- } \\
\text { hydroxybenzoate }\end{array}$ \\
\hline
\end{tabular}

を検討したところ, $\mathrm{pH}$ 及び時間依存的な減少が認 められた [Fig. 5(A)]。さらに，テトラサイクリン 原末を中性及び塩基性溶液にて溶解した際，外観が 黄色から黒褐色に変化した。一方，ナジフロキサシ ンでは，いずれの液性においても，その色彩変化は 観察されなかった。加えて，酸性条件下において， 調整 1 時間後に，急激な濃度の減少を認めたが，中 性・塩基性条件下では変化を認めなかった［Fig. 5 (B) ] 。軟膏混合物抽出液における見掛けの $\mathrm{pH}$ は 7.8 を示し (Fig. 4)，これらの結果は，Fig. 3(B)に
示す軟膏混合物中のナジフロキサシン含量が低下し ないことと一致する。加えて，テトラサイクリン は，アルカリ条件化において，外観色の変化やその 濃度の減少が認められたことより，Fig. 2 に示す軟 膏の色彩変化，及び Fig. 3 (A) に示す含量低下を生 じると考えられる.

混合により主薬含量の低下を認めたことより，伝 染性膿痂疹の標準菌株である S. aureus を用いて, その抗菌活性の変化を検討した。 テトラサイクリン 軟膏とナジフロキサシン軟膏を混合した際，それら 単独群に比して，抗菌活性の有意な低下が観察され た (Table 1)。これらの結果は, pH 変化に伴う主 薬含量の低下に起因した抗菌活性の減弱と考えられ る.

本研究にて，テトラサイクリン軟膏とナジフロキ サシン軟膏を混合することにより，抗菌活性の低下 が観察され，その要因として主薬と添加剤による 酸・塩基反応が関与していることを示した。したが って，これらの軟膏を混合調剂することは避ける心゙ きと考える．しかし，これら軟膏を混合する必要が ある場合は，pH 5.0-7.0では，両主薬含量の低下 が観察されなかったこと（Fig. 5）より，混合軟膏 の $\mathrm{pH}$ を調節する必要があると考える.

今後，製薬企業は市販されている軟膏製剤に含有 されている添加剤の詳細な情報を提供するべきであ る，加えて，われわれ薬剤師は，軟膏を混合する 際，主薬のみならず添加物による配合変化も十分に 注意する必要がある. 


\section{REFERENCES}

1) Ethou T., Hifubyou Shinryou, 24, 363-368 (2002).

2) Ohtani M., Nakai T., Ohsawa K., Kim S, Matsumoto M., Etoh T., Kariya S., Kanou S., Uchino K., Yakugaku Zasshi, 122, 1153-1158 (2002).

3) Ozawa K., Yoshikawa K., Gekashinryou, 88, 374-377 (2003).

4) Ohtani M., Yokoyama M., Kotaki H., Sawada Y., Iga T., Jpn. J. Hosp. Pharm., 19, 493502 (1993).

5) Ohishi T., Shinagawa R., Okazaki Y., Tanabe T., Med. Drug J., 29, 1415-1424 (1993).

6) Nagatani K., Ohishi T., Shinagawa R., Harada Y., J. Jpn. Soc. Hosp. Pharm., 26, 45-51
(1990).

7) Ohishi T., Tanabe T., Shinagawa R., Yamasaki K., J. Jpn. Soc. Hosp. Pharm., 12, 1449-1450 (1995).

8) Ohtani M., Jpn. J. Pharm. Health Care Sci., 29, 1-10 (2003).

9) Goto K., Miyashita M., Hirama A., Kato K., Sumitani S., Ohishi H., J. Hokkaido Soc. Hosp. Pharm., 19, 42 (1977).

10) Umezawa O., Sugihara M., "Yakuzaigaku," eds. by Murata T., Fukuoka E., Koizumi T., Nankodo, Tokyo, 1995, p. 58.

11) Interview form of Acuatim cream, lotion, ointment (Otsuka Pharmaceutical Co., Ltd.) .

12) Interview form of Achromycin ointment (Kayaku Co., Ltd.). 